Michael W. DeLashmutt University of Glasgow, Department of Theology and Religious Studies

Home Address:

Flat $2 / 2$

No. 1 Woodlands Terrace

Glasgow

G3 6DD

United Kingdom

$\underline{\text { mwdelashmutt@yahoo.co.uk }}$

+44(0) 1413530380

\title{
Syncretism or Correlation: Teilhard and Tillich's contrasting methodological approaches to science and theology.
}

\begin{abstract}
This paper revisits Paul Tillich's theological methodology, and contrasts his practice of correlation with the syncretistic methodological practices of Teilhard de Chardin. I argue that the method of correlation, as referred to in Robert John Russell's 2001 Zygon article, fails to uphold Tillich's self-limitation of his own methodology with regard to Tillich's insistence upon the theological circle. I assert that the theological circle, as taken from Systematic Theology I, is a central facet within Tillich's methodology and that this often ignored concept needs to be resuscitated if one is to remain authentically Tillichian in one's approach to the science and theology dialogue.
\end{abstract}

\section{Keywords}

Paul Tillich; Teilhard de Chardin; Robert John Russell; Method of Correlation, Theological Circle; David Klemm; Christology; Cosmology; Syncretism; Einstein; Evolution; Science; Theology; Religion; Theological Method

\section{Preface}

My research began as an attempt to understand the ways in which Tillich and Teilhard uniquely approached the science-theology dialogue in their own day. My original assumption was that the only difference between their works would be the objects of their scientific inquiry, e.g. evolution for Teilhard, and what I hypothesized to be post-Einsteinian cosmology for Tillich. What I discovered was more than a topical difference, but a radical distinction in their various perspectives on the science- 
theology interface. I argue that identifying this difference has extensive implications for the use of Tillich in this dialogue as it stands today.

\section{Introduction}

Pierre Teilhard de Chardin and Paul Tillich were both keenly aware of the important role which science and technology play within culture. In order to present a theology which was in keeping with an increasingly scientific worldview, both scholars accommodated scientific and technological language within their theologies. For Teilhard and Tillich the language of the sciences opened a new world of theological investigation, and increased the viability of theological discourse in an increasingly sceptical and disinterested culture. Yet, the extent to which their respective theologies accommodated scientific language contrasts greatly. As this paper will assert, the chief difference is a methodological one.

Teilhard's approach, as both a palaeontologist and a theologian, was to integrate not only the language of science but the ideas, concepts and goals of a scientific worldview as well. Science contributed greatly to the development of his theology, both in regards to his scientifically informed anthropology and his cosmic eschatology. And likewise, Teilhard's pursuit of the sciences was radically altered by its encounter with confessional Christian theology. In contrast, despite sharing a similar interest in science and theology, Tillich's methodological approach to this interchange was radically different. Whereas Teilhard practiced what I see as a wholesale syncretism of science and theology, Tillich's later definition of the method of correlation clearly prohibited such a coupling between the two disciplines. The separation between science and theology can be highlighted in Tillich by his reference to the 'theological circle' - the semi-permeable membrane which protects the theologian-qua-theologian from becoming theologian-cum-scientist. The theologian's 
place within the theological circle forces his engagement with other disciplines to occur only within the realm of theological reflection. I will argue that if the science and theology dialogue is to continue using Tillich's method of correlation as a foundation for theological method, to be true to Tillich it must begin to utilise his concept of the theological circle. To illustrate my point, I will dialogue with Robert John Russell's 2001 Zygon article, 'The Relevance of Tillich for the Theology and Science Dialogue', and argue that the approach taken by Russell, though viable and valuable, is not Tillichian, or at least not Tillichian in respect to his Systematic Theology I.

\section{Teilhard de Chardin: Syncretism in Science and Theology}

Teilhard in Christianity and Evolution, asks, 'What form must our Christology take if it is to remain itself in a new world?' (Teilhard 1969,76$)$ The new world which Teilhard identifies is a world which is aware of its own evolutionary history. Gone is the naïve belief in a primal origin of the world, founded in the unmediated creative activity of the Divine. The new world's creation myth is based on a collection of random chances and is no longer inspired by a belief in the intentional activity of the finger of God. Because of Teilhard's intellectual commitments - one to the natural sciences and the other to the faith of the Jesuit Order - he needed to reinterpret Christology to make it meet 'the requirements of a world that is evaluative in structure...' (Teilhard 1969, 78) What was at stake for Teilhard was nothing less than the very efficacy of Christian worship, for 'if a Christ is to be completely acceptable as an object of worship, he must be presented as the savior of the idea and reality of evolution.' (Teilhard 1969, 78) 


\section{The Cosmic Christ}

In order to make sense of evolution in light of Christian theology, Teilhard made accommodations both to strict evolutionary theory and to Christian cosmology and Christology. His was a Christocentric view of evolution. He wrote:

$[I] t$ is then, in this physical pole of universal evolution that we must...locate and recognize the plenitude of Christ...no other type of cosmos, and in no other place, can any being...carry out the function of universal solidation and universal animation which Christian dogma attributes to Christ. (Teilhard 1970, 68)

Christ's place in the evolutionary process is described by Teilhard variously as the 'the Omega Point', Christus Evolutur, and 'the Cosmic Christ.' Indeed, as we shall see, the 'cosmicisation' of Christ is equally crucial for both Teilhard's Christology and his understanding of evolutionary theory.

According to Teilhard, Christ is the energy behind all cosmic history; he is both the source and goal of human existence. He states that, 'Christ occupies for us, hic et nunc [everything and nothing] as far as position and function are concerned... [He is]...the place of the point Omega'. (Teilhard [1943] in Wildiers 1967, 135) All of existence is held together by Christ and collimates in him. The whole of cosmic history points towards its fulfillment in the unification of all humanity (and the cosmos) into the eschatological community of which Christ is the head.

By ascribing to Christ the title of 'Point Omega', in his vernacular Teilhard is saying that Christ is the zenith of cosmic history. Quite literally, all things are created in Him, and are destined for unification with Him. Christ as end-point signifies the end of evolution, but more importantly implies that evolution has some defined goal to which it strives. In Christ, at the end of time and space, all the vastness of cosmic disparity will end in ultimate unity and unification. Time and space converge onto the Point Omega inasmuch as evolution's goal is met in the person of the Cosmic Christ the very meaning of history. 
Teilhard's contribution to $20^{\text {th }}$ century thought cannot be minimized. He recognized the impact which scientific discovery makes upon culture and ergo theology, and believed that science and theology could coexist without jeopardizing the unique place of the other. Teilhard's question, 'Why must Christ be revealed in the evolutionary process?' can be answered simply enough; Humanity's discovery of the evolution of all life, forces theology to re-understand Christ's role in the universal and multifarious variations of this life. Yet Teilhard's position, no matter how noble it may appear, is plagued by two crucial problems which are the direct result of his wholesale syncretism of science with Christian theology.

First, Teilhard's reading of evolution through Christology assigns to the cosmic work of Christ a maleficence of character. I have found Moltmann's critique of Teilhard to be helpful at this point. In the Way of Jesus Christ ${ }^{\mathrm{i}}$, he agrees with Teilhard that there are benefits to be found in speaking of Christ in cosmic terms, yet he firmly disagrees with Teilhard when it comes to identifying Christ with the force behind evolution. Moltmann is concerned that Teilhard's position places priority on the goal of evolution, over and against the 'myriads of faulty developments and the victims of this process [who] fall hopelessly by the wayside.' (Moltmann 1993, 292) The second problem with Teilhard's theory stems from the teleological claims which he makes regarding the evolutionary process itself. With the exception of proponents of intelligent design or the so-called anthropic principle, evolutionary teleology is nearly unanimously decried by contemporary evolutionary biologists and theorists today.

If the idea of Christ as the agent of evolutionary selectivity is unacceptable to theology, and if a teleological view of evolution is no longer in scientific vogue, than we must ask ourselves if there is any value to be had in attempting to create a 
synthesis of evolution and Christology, or for that matter, a synthesis of science and theology. I argue that there is really no benefit to be found in synthesizing the two; at least in respect to the methodology employed by Teilhard. Rather, I wish to suggest that the best option for a true dialogue between science and theology is one which honors Tillich's method of correlation, viz. his insistence upon the theological circle.

\section{Paul Tillich - Self-limited Correlation in Science and Religion}

According to Tillich, a theological system is first of all a 'function of the Christian church.' As such, theology must, 'serve the needs of the church', which implies that it must 'satisfy two basic needs: the statements of the truth of the Christian message and the interpretation of this truth for every new generation.' (Tillich 1964a, 1:3) By making the church and the 'spiritual life of the church' the domains of systematic theology, Tillich situates all theological dialogue within the milieu of confessional faith. But the ecclesial situation in which theology arises is not set apart from greater cultural influences. Theology when communicated to 'every new generation,' must take a detour through categories of culture in order for its message to remain contemporaneous within the situation of the church. To do so, theology incorporates the categories (though not the content) of other cultural forms.

Tillich's self-styled theology is an apologetic theology. That is, one which addresses the common ground between the situation of theology, and the situation of culture. But the nature of this apologetic theology is one which only engages with culture in a self-limited fashion. According to Systematic Theology I a theologian's practice of correlation can only proceed from within the domain of the theological circle. Any casual reader of Tillich's theology will note that his work perennially explores the relationship between theology and a variety of alternative disciplines 
(e.g. science, philosophy, sociology and depth psychology). Though these disciplines are helpful in explaining certain domains of reality, they leave bobbing in their wake, basic yet unanswered questions about the existential situation of humanity; questions which a kerygmatic/apologetic theology gladly answers through the structure of Christian Revelation (Tillich 1964a, 1:59ff). Though there may be a close relationship between these various disciplines and theology, they are separated on two fronts: their differing functions (the kinds of questions they ask) and their differing objects (the kind of answers they seek). For Tillich, a Christian theologian approaches the objects of all other disciplines only through the lens of theological symbolism (Tillich 1964a, 1:29).

Tillich is resolute that Christian theology can have no other object (no other 'content') besides the object of ultimate concern. A theology which remains within the theological circle, can never try to function in an authoritative way in matters of penultimate or 'preliminary concern'. This includes the arenas of aesthetics, science and physical theory, artistic creation, historical conjecture, medical healing, social reconstruction and political and international conflicts (Tillich 1964a, 1:15). For Tillich, there is no Theological-art, Theological-science, Theological-history, Theological-medicine, Theological-sociology, or Theological-politic. Tillich asserts that:

The theologian as theologian is no expert in any matters of preliminary concern. And, conversely, those who are experts in these matters should not as such claim to be experts in theology. The first formal principle of theology, guarding the boundary line between ultimate concern and preliminary concerns, protects theology as well as the cultural realms on the other side of the line (Tillich 1964a, 1:15).

\section{Tillich and Science}

Tillich provides us with a myriad of examples from which we can observe how the method of correlation and the theological circle are implemented in his own pursuit of interdisciplinary dialogue. For the sake of brevity, I wish to discuss here 
what I consider to be one of the more important examples, Tillich's essay: 'Science and Theology: A Discussion with Einstein'. In this brief work, Tillich approaches the key theological questions which have been raised by Einstein, and engages in a robust theological apologetic. It is important to note that Tillich does not remove himself from the theological circle, but remains resolutely (and confessionally) theological. The catalyst for Tillich's essay was a speech made by Einstein, in which he rejected the belief in a personal God. The four grounds upon which Einstein based his position were in no way new or innovative, but demanded attention nonetheless, as such statements 'became significant' coming from the 'mouth of Einstein, as an expression of his intellectual and moral character.' (Tillich 1964c, 127)

According to Einstein, the idea of a personal God was not an essential part of religion. Rather, he saw it as a vestigial doctrine which emerged from primitive religious superstition. In light of our modern condition, this belief was not only seen as self-contradictory (inasmuch as a supreme being such as God could not possibly be both perfect and personal) but also contradictory to the scientific worldview which Einstein wished to promote. By making such statements, Einstein as a physicist-cumcultural icon, moved from the scientific circle of his own discipline into the domain of Tillich's theological circle. It was in this context that Tillich's apologetic and kerygmatic theology could truly engage with the ultimate concern conveyed by Einstein's science. As such, Tillich argues on theological grounds that Einstein's claims regarding the self-contradictory and scientifically-contradictory aspects of the belief in a personal God, were based upon Einstein's misunderstanding of the symbol 'personal god'. The relationship between science and theology is a tenuous one, but Tillich's example shows that this relationship is best experienced when either partner shows respect for the other's area of specialty. Just as science cannot speak 
authoritatively to theology, theology cannot build doctrinal affirmations upon 'the dark spots of scientific research.' (Tillich 1964c, 129) Furthermore:

theology...must leave to science the description of the whole of objects and their interdependence in nature and history, in man and his world. And beyond this, theology must leave to philosophy the description of the structures and categories of being itself and of the logos in which being become manifest. Any interference of theology with these tasks of philosophy and science is destructive for theology itself. (Tillich 1964c, 129)

This does not mean that science and philosophy are worthless endeavors! On the contrary, Tillich asserts here that theology, science and philosophy simply pursue different kinds of questions and purvey different kinds of answers. Tillich acknowledges that science can potentially lead one to the 'experience of the numinous', (Tillich 1964c,131) and to an awareness of the groundless ground of being; yet at this turn, the scientific enterprise becomes a theological conveyance. The theological meaning arises from such inquiries when the experience of scientific discovery is mediated through personal, communal and ritual religious experiences which convey cultural events (such as scientific discovery) through the experience of religious presence in symbolic forms.

In examining the way in which Tillich engages with Einstein in this instance, we see an example of his own use of the theological circle. According to the rule of the circle, Tillich's method of correlation only functions at the point of synapse between science and theology, and not in a viral encounter, conquest, or merger of the two disciplines. Tillich's theology answers science when science poses to theology a challenging question. Science, as a cultural force, can convey ultimate concern, and it is only at this juncture that it can be addressed by theological language. Moreover, Tillich's approach hints at the nature of the different epistemological structures of scientific and theological language. For Tillich, 'scientific language is predominantly calculating and detached and religious language is predominantly existential or 
involved.'(Tillich 1988b, 162) Furthermore, he asserts that science and theology describe two different 'dimensions' of reality. Science deals with interrelations within the finite dimension, and theology and religion concern themselves with the dimension of meaning and being in the infinite dimension. Speaking about one dimension is rather different than speaking about the other (Tillich 1988b, 161).

\section{Bringing back the circle}

I understand the import of the theological circle to be broadly reaching for the use of Tillich in interdisciplinary discourse. However, my position is not one which is held unanimously by Tillich scholars or by those interested in the science-theology dialogue. In particular, it stands in tension with Robert John Russell's Zygon article, 'The Relevance of Tillich for the Theology and Science Dialogue' published in June 2001. Russell's article makes some very insightful observations about the role that Tillich's' method of correlation can play in this emerging interdisciplinary field. It is with much respect for Russell's work and a measure of humility, that I offer the following corrective opinion. Although I agree with Russell that Tillich could be useful for this contemporary dialogue, I disagree with his use of Tillich, and in particular with his modification of the method of correlation.

Throughout his article, Russell takes a somewhat selective attitude towards Tillich's methodology. He retains those aspects of Tillich which best suit his interdisciplinary interests, yet discards those positions which do not. To this end, his analysis is completely without any reference to the theological circle, which I believe is the chief difference between Tillich's engagement with the sciences and, by contrast, the syncretism embodied by the work of Teilhard.

Russell argues that for science and theology to have a fruitful conversation, the 'dialogue requires cognitive input from both sides.'(Russell 2001, 270) 
According to Russell, such a conversation is facilitated best by Tillich's method of correlation, which he thinks can be seen as a 'precursor of what is now one of the most productive methodologies in the growing interdisciplinary field of theology and science.'(Russell 2001, 270) Furthermore he argues that a 'theological methodology....should be, and in fact already is, analogous to scientific methodology.' (Russell 2001, 270) His position is influenced by other forms of epistemic ordering which are found in the work of such science-minded theologians as Nancy Murphy, John Polkinghorne and Arthur Peacocke. This has also been advocated in a somewhat modified form by David Klemm and William Klimsky, in their recent Zygon article about the possibility of science-based theological modeling. ${ }^{\text {ii }}$ According to Russell, the open dialogue which is presently experienced between the sciences and theology is a creative mutual interaction which can be credited to Tillich's work in the method of correlation, especially from Systematic Theology I (Russell 2001, 270).

To express his position, Russell sites the work of Barbour, et al., regarding the similarities between science and theology, namely that doctrines can be read as scientific hypothesis which are held,

fallibly and constructed in light of the data of theology..... combination of scripture tradition, reason, personal and community experience, and the encounter with the world culture and with nature, including the discoveries and conclusions of the social, psychological and natural sciences. They are held seriously but tentatively, and they are open to being tested against such data. (Russell 2001, 273)

Furthermore, according to Russell, theological doctrines must be allowed to stand or fall based upon developments in natural sciences. For example,

[T] he theories and discoveries of cosmology, physics, evolutionary and molecular biology, anthropology, the neurosciences, and so on, should serve as crucial sources of data for theology, both inspiring new insights and challenging traditional, outmoded conceptions of nature. (Russell 2001, 273)

Russell acknowledges that scientists such as 'Schrödinger, Einstein, Bohr and Hoyle'

(Russell 2001, 277) were all shaped and effected by either a religious or 
philosophical, pre-scientific disposition. These dispositions effected the way in which these scientists engaged with their field of research. Yet beyond theology's tacit impact, Russell seems to encourage even more input from the part of the theologian. The dialogue which he calls for between science and theology is one which is situated within an 'open intellectual exchange between scholars, based on mutual respect and the fallibility of hypotheses proposed by either side, and based on scientific or theological evidence.' (Russell 2001, 276)

At first glance, this seems like an amenable solution. After all, it seems only fair that if theology is going to be dictated to by the sciences, the sciences should be required to listen to theology as well. Would this not indicate an egalitarian remedy to the problem of an epistemological hierarchy, whereby scientific knowing is placed above all else? Indeed, this would almost appear to be a form of correlation, a dialogue, an interchange, a meeting in which despondent disciplines converge and learn from one another in a kind of academic koinonia. Though this is certainly a viable option for the science and theology dialogue to pursue; this kind of interpenetration is not what is allowed for by Tillich's method of correlation.

Russell creates a distillation of Tillich's methodology, and applies it selectively to his own interests in science and theology. What is significantly missing in his approach is any mention of the theological circle. Although in early and later Tillich, the theological circle was less emphasized (leaving the door open to interdependent dialogue between theology and other disciplines); in the Tillich of Systematic Theology I (the primary Tillich source used by Russell in his article), the theological circle prohibits the type of ideological syncretism which Russell is espousing. 
Russell's position fails to recognize that the underlying foundation of Tillich's theological circle is the belief that theology, as based upon revelation, experiences 'knowing' in a different way than do the sciences. ${ }^{\text {iii }}$ Tillich states that 'knowledge of revelation does not increase our knowledge about the structures of nature, history, and man.' (Tillich 1964a, 1:129) Revelation and the miraculous operate on a level which points to the 'mystery of being', yet does not contradict 'the rational structure of reality.' This implies that revelatory events are ontologically disconnected from natural events. Nonetheless, miracles, religious ecstasy and revelation do not destroy the 'structure of cognitive reason,' thus Tillich implores the reader to allow such events to remain open to 'scientific analysis and psychological, physical...[and] historical investigation.' Tillich encourages this kind of investigation because he is confident that,

revelation belongs to a dimension of reality for which scientific and historical analyses are inadequate. Revelation is the manifestation of the depth of reason and the ground of being. It points to the mystery of existence and to ultimate concern. It is independent of what science and history say about the conditions in which it appears; and it cannot make science and history dependent on itself. No conflict between different dimensions of reality is possible. Reason receives revelation in ecstasy and miracles; but reason is not destroyed by revelation, just as revelation is not emptied by reason. (Tillich 1964a, 1:130-1)

Tillich's use of multiple dimensions of reality facilitates his method of correlation by preventing claims to 'truth' (in the sense of the ultimate) from being made contingent upon the preliminary, thus prohibiting one from reverting to what Russell terms ‘epistemic reduction' (Russell 2001, 280). Yet, despite the fact that Russell is quick to laud Tillich's multi-dimensionality as a panacea for 'epistemic reduction', he contradicts Tillich's overall methodology by asserting that, 'scientific theories' may 'offer modest and indirect support to theological theories by serving as data to be explained theologically or as data which then tends to confirm theology.'(Russell 2001, 280) 
Russell seems to wish to encourage an open dialogue between science and theology where theology can offer theologically inspired scientific observations to science, and science can offer scientifically inspired theological observations to theology. Yet this pursuit seems paradoxical to me, as Russell leaves the theologian severely limited in his/her ability to contribute to this dialogue. Russell's so-called 'asymmetrical' type of relation allows theologians a limited voice when engaging with the sciences. In one example, he sites how a theologian may engage with a physicist; yet the theologian's engagement is crippled, as he is forbidden from appealing to 'some special kind of authority, whether based on scripture, church dogma, magisterial pronouncements, or whatever.' (Russell 2001, 280) In light of this epistemic limitation I wonder whether a theologian would have anything sensible to say at all. With scripture, dogma, and pronouncements removed from the theologian's cache, on what basis does a theologian speak? Is not theological proclamation based upon divine revelation which is ascribed by the community a 'special' kind of authority' and recognized by most to be either 'magisterial' or 'scripture'? If theology is to follow a scientific methodology which uses scientific forms of verification, how can theories-cum-doctrines be created without these essential elements? It would seem that in this kind of relationship, the confessional theologian has little room to work. Although secular theology could thrive in this environment, the type of theology which Tillich offers us is removed from its ecclesial and communal context, and thus looses its kerygmatic edge.

By making science and theology interdependent dialogue partners, one fails to uphold Tillich's ideal of the theological circle, and in so doing disregards his basic belief that theological truth is different from scientific truth. We learn from Tillich that religious truth claims describe the world in different ways than do scientific truth 
claims. The theologian bases his propositions on experience of ultimate concern,

(whether communal, individual, or historical) and operates within a world of texts, of myths, and of interpretations of culture. The 'hypothesis' of Christian ecumenism credo in Deum Patrem, cannot be dissected in the laboratory for analysis; it is simply believed in faith.

The problem of a Tillichian correlation transforming into a Teilhard-esque syncretism, is reminiscent of the 2003 debate opened in Zygon regarding the efficacy of theological modeling. David Klemm and William H. Klink wish to argue that theological propositions can be defended from a methodological position which is similar to that used by the sciences. In response to this, Langdon Gilkey writes the following poignant warning, which is apply suited to our matter at hand.

[T] here is at best only an analogy between the cognition achieved in science and that sought for in theology...I believe that we can in truth speak of cognition, of knowledge, and of truth in the area of theology; but we need to be very careful neither to claim it to be too similar to scientific cognition nor to deny any possibility of cognition. Above all, we need to recognize that there are seemingly different levels of truth and so different modes of cognition and of knowledge at best analogical to one another (Gilkey 2003, 533).

\section{Conclusion}

In the context of the science and theology dialogue it would seem that the example of Teilhard's syncretism is often mistakenly read into Tillich's method of correlation. If we truly wish to use Tillich for this dialogue, I suggest that we pause and reflect upon his own words regarding the problems of interdisciplinary epistemology:

Attempts to elaborate a theology as an empirical-inductive or a metaphysicaldeductive "science," or as a combination of both, have given ample evidence that no such attempt can succeed (Tillich 1964a, 1:11).

As Tillich would have understood it, apologetic/kerygmatic theology is based upon an 'epistemology' which is more about an ontological encounter with ultimate concern than it is about acquired knowledge based upon deduction. The risk in too closely 
knitting the content of theology with the content of the sciences is the reduction of the ontic nature of theological experience into the noetic and epistemological nature of scientific deduction.

Theological discourse is not something which is grasped firmly in the hand, but something which is accepted from the stance of a second naïveté. This does not mean that theology cannot cope with (or appropriate) certain aspects of the sciences, as they reflect an overarching form of cultural habituation; but it does imply that if theology is to be true to its message and history, it must remain dedicated to the existential and the symbolic. Science, with its emphasis on epistemological certainty, deduction, and empiricism does not often leave room for the symbolic, existential or transcendental nature of theology.

In 1958, when Tillich's innovative theology was seen as either being a step forward in translating Christian theology into the parlance of the world, or a step backwards in sacrificing the kerygma at the altar of culture, an editor at Theology Today wrote that he wondered; 'whether in representing and translating the Gospel for our day Tillich actually provides new meaning for old truth or only succeeds in perverting and distorting what is essentially Christian.' (Kerr 1958, 10) One wonders in light of the present use of Tillich in the science and theology dialogue, if representing and translating Tillich for our own day, the science and theology dialogue provides new meaning of old truth, or only succeeds in perverting and distorting what is essentially (or existentially) Tillichian.

\section{Reference List}

Gilkey, Langdon "Problems and Possibilities of Theological Models: Responding to David Klemm and William Klink." Zygon 38, no. 3 (2003): 529-534.

Kerr, Hugh T. "Living on the Growing Edge." Theology Today 15, no. April (1958): 8-12. 
Klemm, David E. and Klink, William H. "Dialogue on Theological Models: Constructing and Testing Theological Models." Zygon 38, no. 3 (2003): 495-528.

Moltmann, Jurgen "Hope and History." Theology Today 25, no. October (1968): 369-386.

Moltmann, Jurgen. The Way of Jesus Christ: Christology in Messianic Dimensions. Minneapolis: Fortress, 1993.

Russell, R.J. "The Relevance of Tillich for the Theology and Science Dialogue." Zygon 36, no. 2 (2001): 269-308.

Teilhard de Chardin, Pierre. Christianity and Evolution. New York: Harcourt Brace Jovanovich, Inc., 1969.

Teilhard de Chardin, Pierre "The Confluence of Religions." Theology Today 27, no. April (1970): 63-70.

Tillich, Paul. "The relationship today between science and religion." In The Spiritual Situation of our Technical Society, Ed. J.M. Thomas, 77-82. Macon, Ga.: Mercer, 1988.

Tillich, Paul. "Religion, Science and Philosophy." In The Spiritual Situation of our Technical Society, Ed. J.M. Thomas, 159-172. Macon, Ga.: Mercer, 1988.

Tillich, Paul. Systematic Theology I. Digswell Place: James Nisbet \& Co. Ltd., 1964.

Tillich, Paul. Systematic Theology II. Digswell Place: James Nisbet \& Co. Ltd., 1964.

Tillich, Paul. "Theology and Science: A Discussion with Einstein." In Theology of Culture 127-132. London: Oxford University Press, 1964.

Tillich, Paul. Systematic Theology III Digswell Place: James Nisbet \& Co. Ltd., 1968.

Wildiers, N.M. An Introduction to Teilhard de Chardin. New York: Harper and Row, 1968. 


\section{Author's Note}

Michael W. DeLashmutt is a PhD candidate at the University of Glasgow in the Department of Theology and Religious Studies, researching under the joint supervision of The Rev'd Prof Dr. David Jasper (Glasgow) and The Rev'd Canon Dr. Michael Fuller (Theological Institute of the Scottish Episcopal Church). His departmental address is: No. 4 The Square, University of Glasgow, Glasgow, G12 8QQ, United Kingdom. This paper was originally presented in an abbreviated form at the 2003 annual meeting of the North American Paul Tillich Society, in conjunction with the annual meeting of the American Academy of Religion in Atlanta, Georgia, November 2003.

\section{Word Count: 5,380}

\footnotetext{
${ }^{\mathrm{i}}$ In his Theology Today essay, "Hope and History", Moltmann criticizes the worldview, from which Teilhard develops his theology. He argues against a cosmological metaphysic, from which God's existence is proved through phenomenology, because humanity's identity is no longer rooted in a connection with the cosmos qua cosmos. (Moltmann 1968, 369-386.)

${ }^{i i}$ For further information, see: David E. Klemm and William H. Klink, "Dialogue on Theological Models: Constructing and Testing Theological Models," Zygon 38, no. 3 (2003): 495-528

iii Tillich argues for the theological circle, as a means of providing an alternative compromise to the conflicting theological epistemologies of Barth and Bultmann. This issue became less pressing in Tillich's later work, and so the theological circle is not as prevalent a theme. Despite this, I contest that the theological circle still remains an important issue when one considers implementing a Tillichian methodology.
} 